Recepción: 01 / 02 / 2018

Aceptación: 15 / 04 / 2018

\title{
Guanxi, Social Capital and Networking
}

\author{
Guanxi, Capital Social y Redes
}

Gema I. Sornoza-Parrales ${ }^{\text {I }}$

gema@sornoza.com

Adrián O. Macías-Loor II

adrianmacias@thasesoria.com

Adriana Castillo-Merino III

adriana.castillo@unesum.edu.ec

Sandra P. Toala-Bozada IV

spt bozada@yahoo.com

Mónica del Pilar Quinónez-Cercado ${ }^{\mathrm{V}}$

mquinonez78@hotmail.com

Carmen A. Álvarez-Vásquez VI

carmenalvarezavz@hotmail.com

Correspondencia: gema@sornoza.com

I. Renmin University of China, Ingeniera en comercio y finanzas internacionales, bilingüe, Manta, Ecuador.

II. Docente, Universidad Estadal del Sur de Manabí, Jipijapa, Ecuador.

III. Docente, Universidad Estadal del Sur de Manabí, Jipijapa, Ecuador.

IV. Universidad estadal del Sur de Manabí; Magister en docencia universitaria e investigación educativa; Doctora en administración; Diplomado en autoevaluación y acreditación universitaria.

v. Docente, Universidad Estadal del Sur de Manabí; Jipijapa, Ecuador.

VI. Docente, Universidad Estadal del Sur de Manabí, Jipijapa, Ecuador. 


\begin{abstract}
This article synthesizes the meaning and importance of Guanxi which is describes as the basic dynamics of personalized networks of influence and constitutes a central concept in Chinese society. Based on their own definitions of relationships, the West usually interprets it as a set of relationships and connections. However, it is much more complicated and intricate. Guanxi is one of the most powerful forces in Chinese culture, encompassing the idea of a complex series of connections of individuals and families with which a person is connected. Guanxi is created and deepened over time and brings with it a great responsibility in terms of social exchanges and favors. Understanding the role of Guanxi in business is very important to develop fruitful relationships in China. The nature of Guanxi reciprocity and the implicit obligations are one of the main reasons why the Chinese are reluctant to embark on deep business relationships with people they do not know. Literally "Guanxi" means the connection between two or more people through a relationship of mutual dependence that includes the realization of reciprocal personal gifts and favors.
\end{abstract}

Keywords: Guanxi, Social relationship, Chinese people. 
Gema I. Sornoza-Parrales; Adrián O. Macías-Loor; Adriana Castillo-Merino; Sandra P. Toala-Bozada; Mónica del

Pilar Quinónez-Cercado; Carmen A. Álvarez-Vásquez

\section{Resumen}

Este artículo sintetiza el significado y la importancia de Guanxi, que se describe como la dinámica básica de las redes de influencia personalizadas y constituye un concepto central en la sociedad china. Con base en sus propias definiciones de relaciones, Occidente generalmente lo interpreta como un conjunto de relaciones y conexiones. Sin embargo, es mucho más complicado e intrincado. Guanxi es una de las fuerzas más poderosas en la cultura china, que abarca la idea de una serie compleja de conexiones de individuos y familias con las que una persona está conectada. Guanxi se crea y se profundiza con el tiempo y conlleva una gran responsabilidad en términos de intercambios y favores sociales. Comprender el papel de Guanxi en los negocios es muy importante para desarrollar relaciones fructíferas en China. La naturaleza de la reciprocidad de Guanxi y las obligaciones implícitas son una de las principales razones por las cuales los chinos son reacios a entablar relaciones comerciales profundas con personas que no conocen. Literalmente "Guanxi" significa la conexión entre dos o más personas a través de una relación de dependencia mutua que incluye la realización de regalos y favores personales recíprocos.

Key words: Guanxi, relación social, pueblo chino. 


\section{Introducción.}

In the 70's China went through a period of changes and reforms that ended up opening the country to the world, since then some Chinese practices has drawn attention and has been studied by scholars from western countries. This is the case of the practice of Guanxi, which is one of the major dynamics in Chinese society and has special importance among Chinese people. It is a concept that has existed in the Chinese society for more than two thousand years (Xueyuan, 2012). Social relationships are very special for Chinese people, as people's family, kinship networks , colleagues, neighbors, classmates, friendship circles, and even casual acquaintances are the social communities into which they grow and on which they depend.

In the other hand Social Capital is a concept that has gained popularity in the last decades and stresses the importance of developing relationships or networks as a resource for social action, it states that social networks can become an asset and bring benefits to the persons among the network.

An important interrogation can be raised as to how Guanxi relates with friendship and networking patterns in the West, the aim of this paper is to first explain both concepts using the existing literature and then compare them in order to understand what similitudes and differences they share. The possibility of considering Guanxi as a variant form of social capital is explored.

\section{Method.}

This research focuses on the study and analysis of Guanxi as a system of social integration which has been a study topic worldwide in the last 30 years.

This is a current bibliographical review of texts, documents and reports available on the web considering that legacy of globalization allows us to access to a more and better information through 
Gema I. Sornoza-Parrales; Adrián O. Macías-Loor; Adriana Castillo-Merino; Sandra P. Toala-Bozada; Mónica del

technological tools. The search engine has been academic tools on the web with specifically address files with validity and recognition.

\section{Development}

\section{Guanxi}

Personal relationships are highly regarded in Chinese society, in the last decades the term Guanxi have gained acceptance and popularity in western literature, Guanxi has recently gained its status as a legitimate socio-cultural construct in Western mainstream literatures of cultural anthropology, sociology, social psychology, political science, and business and management (Chen \& Chen, 2004).

Guanxi is a complex and dynamic term, therefore clarifying the meaning of Guanxi is the first step in this paper. In the most general term, the simple translation of the Chinese word Guanxi is "relationship". The same word can be used either to refer to people, when the word means human relationships; or non-human issues, e.g. Guanxi between price and quantity demand. However when the word appears in English and spelt as Guanxi bases on Beijing's pin-yin system ${ }^{1}$, it refers only to relationships between people. (So \& Walker, 2006)

Pinyin, or Hànyǔ Pīnyīn, is the official Romanization system for Standard Chinese in mainland China and to some extent in Taiwan. It is often used to teach Standard Chinese, which is normally written using Chinese characters.

But in reality a simple English translation in not enough to explain the special nature of the Guanxi, a closer explanation to the term is given by (Jacobs, 1979); commonly used in contemporary Chinese societies, it refers more narrowly to "particularistic ties". Ties that can be 
defined as two or more persons having a common shared identification which is important to the individuals, such as a place of work, hometown, school and so on. No matter if the Guanxi is naturally occurring or created, the important matter is that such relationship must be maintained by mutual commitment, loyalty and obligation (CHEN \& CHEN, 2004)

The roots of Guanxi are related to the Confucianism, modern Chinese society is still very much intact with its Confucian history, stressing "scholarship, hard work, perseverance and social order" (White, 2006). According to Confucianism, an individual is fundamentally a social or relational being. Social order and stability, which was used in Confucianism, depend on properly differentiated role relationships between particular individuals.

According to Bain (1994), Guanxi could refer to one of three things: (a) the existence of a relationship between people who share a group status or are related to a common person, (b) actual connections with and frequent contact between people, and (c) a contact person with little direct interaction.

The core idea of Guanxi involves relationships between or among individuals creating obligations for the continued exchange of favors (Dunfee \& Warren, 2001). Guanxi operates on the basis of long-term relationships which are sustained through trust, mutual obligation and reciprocity (Qi, 2013).

Guanxi is a Chinese word for a universal phenomenon even though the types of particularistic ties and the intensity of their application are different in China compared with other societies (Qi, 2013). 
The importance of Guanxi in China is attributed to the weakness of institutions for managing social, economic and political relations, and allocating resources (Gold, Guthrie, \& Wank, 1998).

Which leads us to the question of, either Guanxi is an exclusive Chinese cultural behavior or does western cultures has its own Guanxi? The fundamental concepts associated with Guanxi can be linked or compared with the concepts of the western term of social capital, as it is often remarked that Guanxi functions as a form of social capital, in which resources derived from interpersonal relationships have values available to the participants (Chen \& Chen, 2004).

\section{Social Capital}

The premise behind the notion of social capital is rather simple and straightforward: investment in social relations with expected returns (Lin, 1999). In this sense, it can be said that the achievement of social capital, depends or is related to the success of networking. Bourdieu(1986), stated that the network of relationships is the product of investment strategies, individual or collective, consciously or unconsciously aimed at establishing or reproducing social relationships that are directly usable in the short or long term.

Loury(1977) in his paper “A Dynamic Theory of Racial Income Differences”, defines social capital with a similar approach to Bourdieu; "the merit notion, that in a free society each individual will rise to the level justified by his or her competence, conflicts with the observation that no one travels that road entirely alone". This statement emphasizes the importance of networking, he continued, "The social context within which individual maturation occurs strongly conditions what otherwise equally competent individuals can achieve”. 
Gema I. Sornoza-Parrales; Adrián O. Macías-Loor; Adriana Castillo-Merino; Sandra P. Toala-Bozada; Mónica del Pilar Quinónez-Cercado; Carmen A. Álvarez-Vásquez

Dekker \& Uslaner, 2001 defined Social capital as being about the value of social networks, bonding similar people and bridging between diverse people, with norms of reciprocity.

Different authors then agree in one thing, the strength of social capital lies in the notion that relations make a difference in the way individuals and groups perform the sorts of resources they acquire, and their general well-being (Prell, 2006).

Then Social Capital is achieved by networking, which is defined as the "building and nurturing of personal and professional relationships to create a system or chain of information, contacts, and support" (Janasz, Dowd, \& Schneider, 2002) the main goal of networking is to help individuals to build social capital, which is defined again by (Bourdieu, 1986) as,

"the aggregate of the actual or potential resources which are linked to possession of a durable network of more or less institutionalized relationships of mutual acquaintance and recognition - or in other words, to membership in a group -which provides each of its members with the backing of the collectivity-owned capital, a credential which entitles them to credit, in the various senses of the word. These relationships may exist only in the practical state, in material and or symbolic exchanges which help to maintain them. They may also be socially instituted and guaranteed by the application of a common name (the name of a family, a class, or a tribe or of a school, a party, etc.) and by a whole set of instituting acts designed simultaneously to form and inform those who undergo them; in this case, they are more or less really enacted and so maintained and reinforced, in exchanges".

Generally, three explanations can be offered as to why embedded resources in social networks will enhance the outcomes of actions. For one, it facilitates the flow of information. Social ties located in certain strategic locations and/or hierarchical positions can provide an individual with 
useful information about opportunities and choices otherwise not available (Lin, Building a Network Theory of Social Capital, 1999).Second, these social ties may exert influence on the agents. Third, social tie resources, and their acknowledged relationships to the individual, may be conceived by the organization or its agents as certifications of the individual's social credentials, some of which reflect the individual's accessibility to resources through social networks and relations. Social relations are expected to reinforce identity and recognition.

The notion of social capital contains three ingredients: resources embedded in a social structure; accessibility to such social resources by individuals; and use or mobilization of such social resources by individuals in purposive actions.

Then social capital is constructed through effective networking, networks provide the necessary condition for access to and use of embedded resources (Lin, A Network Theory of Social Capital, 2005).

From a network perspective social capital is classified in three types: bonding, bridging and linking. Bonding social capital refers to the ties between individuals with a high degree of network closure, this means relationships between similar people such as family or friends or local communities, many members have access to similar network assets so while providing solidarity, bonding social capital may not provide useful network assets in some situations. Then Bridging social capital refers to the establishment of a relationship between people who are not personally close, brings together people across diverse social divisions. It may provide access to network resources outside of an individual's normal circles and as such can provide significant individual (and group) benefits. Finally Linking social capital is about connections with people in power or with influential positions. 
Gema I. Sornoza-Parrales; Adrián O. Macías-Loor; Adriana Castillo-Merino; Sandra P. Toala-Bozada; Mónica del

Comparing social capital with Guanxi then lies in the available concepts that different author along the last decades have given. Guanxi has numerous similarities to bonding social capital, in explaining how a dense community sticks together and helps each other with resources, information and business (Crombie, 2011). It can be said that Social Capital and Guanxi share some common characteristics in regards to the importance of making connections in order to gain benefits. But what are the differences between this two concepts, as regarding to the differences the biggest one relies on the importance or the way those relations are nurtured.

\section{Social Capital and Guanxi}

To some observers and practitioners, Guanxi is an essential and defining element of Chinese culture, handed down relatively unchanged through time and space. To others, Guanxi is little more than a Chinese word for the personal networks, social capital, and gift economies found in all societies (Gold, Guthrie, \& Wank, 1998). As with other forms of capital, Bourdieu is interested in the ability to convert one form of capital into another. Clearly, in China, Guanxi as social capital is accumulated with the intention of converting it into economic, political, or symbolic capital (Gold, Guthrie, \& Wank, 1998).

First let's compare the nature toward some attitudes between Chinese people and people from some western societies, Graham \& Lam (2003) compare Western and Chinese attitudes with the following table: 


\section{Table 1. Differences between Chinese and Western people attitudes}

\begin{tabular}{c|c|}
\multicolumn{1}{c}{ Western } & Chinese \\
\hline Individualistic & Collectivist \\
Egalitarian & Hierarchical \\
Information oriented & Relationship oriented \\
Reductionist & Holistic \\
Sequential & Circular \\
Seeks the truth & Seeks the way \\
The argument culture & The haggling culture \\
\cline { 2 - 2 } &
\end{tabular}

Source: Graham \& Lam (2003)

Chinese culture roots are based on four premises: 1) their agrarian history which stresses the virtues of rural life, 2) Confucius and morality which stresses hierarchy and an organized society as well as Taoism and the yin (feminine, dark and passive) which needs to be reconciled with the yang (masculine, light and active) 3) Chinese words which are really pictures which train them to think in big pictures not the details and 4) a wariness of foreigners (Graham \& Lam, 2003). (Crombie, 2011).Then because of the heavy influence of Confucianism, Chinese often view themselves as interdependent with the surrounding social context. The self in relation to the other becomes the focus of individual experience. This view of an interdependent self is in sharp contrast to the Western view of an independent self. (Pilotta, 2013). The types of particularistic ties and the intensity of their application are different, to Westerners, relationships help the individual; to Chinese people, they also define the individual. Guanxi operates on the basis of long-term relationships which are sustained through trust, mutual obligation and reciprocity. Guanxi is therefore more than a friendship or simple interpersonal relationship; it includes reciprocal 
Gema I. Sornoza-Parrales; Adrián O. Macías-Loor; Adriana Castillo-Merino; Sandra P. Toala-Bozada; Mónica del

obligations to respond to requests for assistance. Unlike inter-firm networking in the West, however, this reciprocity is implicit, without time specifications, not necessarily equivalent, and only socially binding.

As it seems that Guanxi and Social Capital share a close concept, there are some characteristics that gives Guanxi more meaning than social embeddedness and connections.

To understand better first we have to acknowledge the traditional concepts in which Guanxi is based, Guanxi is based on traditional Chinese concepts, especially those of renqing (reciprocal obligation and indebtedness), "face", ganqing (affection), and yiqi (loyalty and righteousness) (Ruan, 2017). The concept of renqing is central to the system of Guanxi, renqing denotes social norms and it gives a sense of indebtedness. The morally infused mutual exchange carried by renqing is the dynamic force behind Guanxi practice. Which at the same time is connected with Confucianism, and the emphasis of the ethics of human relationships

Second, the awareness that Chinese people seems to have about the closeness levels of the Guanxi, and the idea that they act accordingly. Ruan (2017) described the social distance of Guanxi as a continuum divided into close, moderate and distant guanxi. He also compares Guanxi with Social Capital and get the conclusion that Guanxi is a network, while social capital is the ability of actors to secure benefits by virtue of membership in social networks or other social structures. Then Guanxi is more related to the concept of networking which is one if the important elements of Social Capital.

The way Guanxi is practiced also differs with the way networking works in occident, Ruan (2017) proposes a new concept about social capital in Chinese societies, where he points out the importance of rituals, ritual capital as he states; since everyday life is the experience of moving 
through a chain of interaction rituals, in which some symbols are charged with emotional significance, and some interaction rituals, if done properly, will improve one's ability to mobilize social resources. This concept help us to describe and understand better the special ways in which Chinese people deals with the process of making and using social relationships to build up social capital. Some forms of ritual capital can be identified in all societies since different cultures has their own rituals. In Chinese culture however rituals have special importance as a heritage to its long cultural history; for example, Gift giving and entertaining are the two most popular methods of Guanxi practice, since, gift giving is an important part of social etiquette in China, and is used as a way to show the value of a relationship with the aim of expressing respect to the receivers. When practicing Guanxi, gift giving creates some kind of "social debt" that must be reciprocated. Another example is the way business relationships are handled; in the west, personal relationships often develop from business relationships; whereas in China the reverse is true (Zhang \& Goodfellow, 2005). For Chinese people Guanxi must be first created in order to move forward to different matters, for instance, when doing business, Guanxi must be first build and if it is successfully stablished then the transaction may follow. Meanwhile in western societies what is most important is the transaction itself; , networking between the business participants is regarded, at most, "as a pleasant but secondary consequence of the transaction" (Xueyuan, 2012) this kind of practices illustrates how Guanxi is involved in many traditional customs and rituals from Chinese culture.

\section{Conclusion.}

In conclusion, Guanxi is not only related to Social Capital itself but is also connected to the western concept of networking, and is through those practices that social capital is developed. Furthermore, Guanxi shares similarities with the classification of Social Capital from a network 
perspective, Guanxi starts with the family, the extended family and tight groups like classmates and the Party which is similar to the concept of bonding Social Capital. Bridging Social Capital relates to Guanxi, as a common reference person can introduce one person to someone new as a way to access resources and information (Crombie, 2011).Linking Social Capital has also similitudes with Guanxi, since because of the lack of rule of law and the uncertainty in the Chinese transitional economy Guanxi also is established with government officials and officials in other institutions such as banks and regulators. Close personal relationships are also critical.

Both Guanxi and Social capital include trust, mutual obligation and reciprocity within its typical definition, however the Chinese Guanxi has some special characteristics that differentiate it from Networking. The way ties are created and the importance people give to the idea of nurturing and conserving those ties differs from the way Networks are created in western societies, this is mainly due to the idea that for Chinese society rituals and traditions are highly significant. The traditions seem to differ and have an impact on the real nature of connecting and networking.

Finally Guanxi is a fundamental part of interpersonal relations in China and remains important in multiple aspects of Chinese society, but as China is in a period of changes and internationalization is still uncertain what the future holds for the practitioners of the Guanxi, we can't know for sure either this practices will continue or it will lose its important position in Chinese society in the years to come and it will become more oriented to the practices of Social Capital.

So far more and more studies related to this two concepts are emerging, as China is becoming more the focus of attention for western researches who are interested in understanding Chinese practices as is the case of Guanxi. Which means that in the future maybe this two concepts would be kept studied. 


\section{References.}

Bourdieu, P. (1986). The forms of capital.

CHEN, X.-P. \&. (2004). On the Intricacies of the Chinese Guanxi: A Process Model of Guanxi Development. Asia Pacific Journal of Management.

Crombie, B. (2011). Is Guanxi Social Capital? The ISM Journal of International Business.

Dekker, P. \&. (2001). Social Capital and Participation in Everyday Life.

Dunfee, T. W. (2001). Is Guanxi Ethical? A Normative Analysis of Doing Business in China. Journal of Business Ethics.

Gold, T. G. (1998). Social Connections in China. Institutions, Culture, and the Changing. Nature of Guanxi. Cambridge University Press 2004.

Graham, J. L. (2003). The Chinese Negotiation. Harvard Business Review.

Jacobs, B. (1979). A Preliminary Model of Particularistic Ties in Chinese Political Alliances: KanCh'ing and Kuan-Hsi in a Rural Taiwanese Township. The China Quarterly.

Janasz, S. d. (2002). Interpersonal Skills in Organizations.

Lin, N. (2005). A Network Theory of Social Capital. Duke University.

Lin, N. (1999). Building a Network Theory of Social Capital. Connections.

Lin, N. (1999). Building a Network Theory of Social Capital'. Duke University.

Loury, G. C. (1977). A dynamic theory of racial income differences. In P. A. Wallace, \& A. M. LaMond, Women, minorities, and employment discrimination.

Pilotta, J. (2013). Confucius and Contemporary Guanxi. International Journal of Area Studies 8:1, 2013.

Prell, C. (2006). Social Capital as Network Capital: Looking at the Role of Social Networks Among Not-For-Profits. Sociological Research Online.

Qi, X. (2013). Guanxi, social capital theory and beyond: toward a globalized social science. University of Western Sydney.

Ruan, J. (2017). Guanxi, Social Capital and School Choice in China. Springer Nature .

So, Y. L. (2006). Explaining Guanxi, The Chinese Business Network. Routledge.

White, B. (2006). Business in China: Confucianism, Guanxi, and the Modern Chinese Marketplace. Lehigh Review at Lehigh Preserve. Volume 14 - 2006. Paper 10.

Xueyuan, Z. (2012). A Comparison between the Chinese Guanxi and the Western Business Networking. Inner Mongolia Normal University. 
Gema I. Sornoza-Parrales; Adrián O. Macías-Loor; Adriana Castillo-Merino; Sandra P. Toala-Bozada; Mónica del Pilar Quinónez-Cercado; Carmen A. Álvarez-Vásquez

Zhang, X. S. (2005). China Business Culture: Strategies for Success. Singapore: Talisman Publishing Pte Ltd. . 